\title{
OCCURRENCE OF INTESTINAL PARASITES AMONG SCHOOL GOING CHILDREN OF A SLUM AREA IN DHAKA CITY
}

\author{
Md. Rahat Hossain, Sharmin Musa*, Rimi Farhana Zaman \\ and Hamida Khanum \\ Department of Zoology, University of Dhaka, Dhaka-1000, Bangladesh
}

\begin{abstract}
A cross sectional study was carried out among school going children of Ganaktuli slum area in Dhaka city, Bangladesh. A total of 183 stool samples were collected from children of age between 5 and 16 years of both sexes during May, 2017 to April, 2018. Collected samples were examined using Formal-Ether Concentration technique. $61.20 \%$ samples were found positive for intestinal parasites. Eight species of parasites were identified, where Entamoeba histolytica (3.83\%), Giardia lamblia (6.01\%), Diphyllobothrium latum (3.28\%), Paragonimus westermani (3.83\%), Ascaris lumbricoides (24.59\%), Trichuris trichiura (12.02\%), Ancylostoma duodenale (5.46\%) and Enterobius vermicularis (2.19\%) was recorded. Male children showed higher $(63.95 \%)$ prevalence than female $(58.76 \%)$. The highest and lowest prevalence (82.46 and 39.29\%) were found among $8-10$ and 14 - 16 years children, respectively. The highest prevalence of $E$. histolytica (7.02\%), A. lumbricoides (38.60\%), T. trichiura (14.04\%) and A. duodenale $(8.77 \%)$ were observed in 8 - 10 years age group; G. lamblia (7.41\%), P. westermani $(5.56 \%)$ and E. vermicularis $(3.70 \%)$ in 11 - 13 years age group and D. latum $(6.90 \%)$ was found highest in $14-16$ years age group. Statistically it was observed that age groups had significant association with parasitic infestation $(p<0.05)$ but prevalence did not alter significantly according to sexes $(\mathrm{p}>0.05)$. Highest abundance of parasites was recorded for A. lumbricoides.
\end{abstract}

Key words: Children, intestinal parasites, slum area

\section{INTRODUCTION}

It has been estimated that nearly 3.5 billion people worldwide are infected, with children being the majority due to their life style activities and less developed immune system (Vilwanathan et al. 2017). The first five year plan of Bangladesh (1973-78) reported that 645 million of the children of the country suffered from intestinal parasitic infection. One in ten child deaths result globally from diarrheal disease before their fifth birthday, resulting annually 800,000 fatalities were effected worldwide (Liu et al. 2010). In Bangladesh, 1 in 30 children die of diarrhea or dysentery by his or her fifth birthday (Haque et al. 2003) and one third of the total child death occur is due to diarrhea (Victora et al. 1993). It has been also estimated that children aged 5 - 14 years in low

*Author for correspondence: <sharminsumi@yahoo.com>

(c) 2018 Zoological Society of Bangladesh DOI: https://doi.org/10.3329/bjz.v47i1.42022 
income countries, intestinal worms infection account for $12 \%$ of total disability adjusted life years (DALYs) lost due to communicable disease among school children as a result of intestinal nematodes (Odo et al. 2016).

Intestinal parasitic infection represents a relevant clinical problem, especially in developing countries like Bangladesh, where they are responsible for morbidity and mortality in children (Khanum et al. 2016). Diarrheal disease which is one of the consequences of intestinal parasitic infection is still a crucial public health problem globally and hence the World Health Organization (WHO 2002) ranks diarrheal disease as the second most common cause of morbidity and mortality in children in the developing country. These parasitic infections are common among school age children and tend to occur in higher intensities (Seid et al. 2015). People of all ages are affected by the cycle of prevalent parasitic infections; however, children are the worst affected (Steketee 2003, Garzon 2003). Apart from causing morbidity and mortality among children in developing countries, it also leads to growth disturbances, poor academic career and easy susceptibility to other infections (Gelaw et al. 2013). Moreover, parasitic infections have adverse effects on the survival, appetite, physical fitness, school attendance and cognitive performance of school age children (Sharma et al. 2004 and Nematian et al. 2008).

Infections in early life result undernourishment and diarrhea, associated with poor cognitive function at school age (Berkman et al. 2002). Younger children are predisposed to heavy infections with intestinal parasites since their immune systems are not yet fully developed (Rao et al. 2006) and they also habitually play in faecally contaminated soil in developing countries of the tropics.

Poor sanitation and illiteracy make quite a good number of victims of diarrhea and other gastrointestinal parasitic discomforts. The high prevalence of the parasites is usually correlated with poverty, poor environmental hygiene and deprived health services (Uddin and Khanum 2006). Several other factors like climatic conditions, unsafe drinking water, and lack of toilet facilities are the main contributors to the high prevalence of intestinal parasites in the tropical and sub-tropical countries (Ali et al. 1999).

\section{MATERIAL AND METHODS}

The present investigation was aimed to determine the prevalence of intestinal parasites among the school going children aged between 5 - 16 years irrespective of their habit of going to school of Ganaktuli slum area (Hazaribag) in Dhaka city, Bangladesh during May, 2017 to April, 2018. The area is unhygienic and the impoverished children live in Dhaka. A total of 183 stool samples were 
examined from the children of the study area. These children were divided into the following 4 age groups:

(a) 5 - 7 years, (b) 8 - 10 years, (c) $11-13$ years and (d) $14-16$ years.

At first the mothers of the selected children were explained the nature of the experiment to ensure them that the study would not be harmful to the children, rather it would be helpful. The questionnaire was filled up by face to face interview of each mother. The demographic, socio-economic and sanitation of the household were observed and noted in addition to information from the mothers. All the questions asked to the mothers were in Bengali and a local guide always accompanied the researcher for necessary help. Each question was asked clearly to the mother, and answers were recorded accordingly.

After the questionnaire was filled up, an empty plastic container was provided to each mother to collect the fresh stool of the children in the following morning. Provided containers containing stool were then taken in the following morning. The stool samples were then carried away to the Parasitology Laboratory of Zoology Department of Dhaka University for observation.

The following procedures were maintained while collecting the stool samples:

- The stool samples were collected in a clean, dry, leak proof and transparent container. No antiseptic was used. Stool samples were not contaminated with urine

- As far as possible, fresh samples of stool of sufficient amount (6 - $8 \mathrm{~g}$ )

- No de-worming medication was provided to the child before collecting the samples

- Adequate air space was kept in the container

- Suitable preservative was used in case of delayed examination

- Identification number labels were put on the container.

In case of delayed examination, after collection, stool samples were preserved in $10 \%$ formalin and also stored specimens freeze $\left(-20^{\circ} \mathrm{C}\right)$ which could not be performed within $72 \mathrm{hrs}$ of collection.

All the laboratory tests were performed in the Parasitology Laboratory of Department of Zoology, University of Dhaka, Dhaka, Bangladesh. For microscopic examination, formol-ether concentration (FEC) technique was used. Finally the ova and cysts were observed and identified according to following the descriptions by Chatterjee (2014) and Schmidt and Roberts (1989). The data were entered into Microsoft Excel (2010) and analyzed by SPSS version 17.0 and STATA software. Chi square and $\mathrm{F}$ test were used to determine significant differences between variables. $\mathrm{p}<0.05$ was considered significant. The value of Shannon (1959) index $(\mathrm{H})$ was used to determine the parasite diversity and species richness. 


\section{RESULTS AND DISCUSSION}

Out of 183 stool samples examined, 86 from male and 97 from female children, $61.20 \%$ samples were found infected with different intestinal protozoans and helminths. Similar findings were also observed in the investigations of Feleke et al. (2010), Mukutmoni and Khanum (2017) and Hosna et al. (2018). In their study the prevalence rates were 60, 66.04 and $69.39 \%$, respectively.

A total of 8 species of parasites were found in the present study. Prevalence of parasites in male children (63.95\%) was higher than in female $(58.76 \%)$. This fact may be due to the scenario that boys are most commonly exposed to infections due to their excessive outdoor activities when compared with girls. A similar result was also observed by Rahman et al. (2005) and Feleke et al. (2010). Whereas, Khanum et al. (1997), Onyido et al. (2017), Alam and Khanum (2005) reported that females were more infected than males; this is contradictory with the present findings. Association between sex and infection was not found significant at $5 \%$ level ( $2=0.52 ; \mathrm{p}=0.47>0.05)$.

In both male $(27.91 \%)$ and female $(21.65 \%)$ children A. lumbricoides was found the highest prevalence (Table 2). Similar result was also observed by Hosna et al. (2018). Ugochi et al. (2015) found no significant difference of ascariasis between male and female. Whereas Odo et al. (2016) reported higher prevalence in female than in male which contradicts the present findings. The highest prevalence of $A$. lumbricoides implies the high rate of egg production, suitable environment to keep those eggs alive, poor sanitation and ingesting raw vegetables or using contaminated hands. In the present investigation, both Entamoeba histolytica and Giardia lamblia had more infection in female (4.12 and $6.19 \%$ ) than male (3.49 and 5.81\%). Odo et al. (2016) found no significant relation between sex and giardiasis. In the present study, Trichuris trichura had more infection in male $(13.95 \%)$ than female $(10.31 \%)$. Similar result was also observed by Ahmed et al. (2013) and Kumar et al. (2017).

However, Ancylostoma duodenale infection was found more in female (6.19\%) than in male $(4.65 \%)$ which is supported by the study of Hosna et al. (2018) although Khanum et al. (2016) found slightly higher prevalence in male (1.64\%) than in female $(1.31 \%)$ for this particular parasite. Whereas, infection by Paragonimus westemani and Diphyllobothrium latum was found higher in male (4.65 and 3.49\%, respectively) and lower in female (3.09 and 3.09\%, respectively). Only female were found to be infected by Enterobius vermicularis and the infection rate $4.12 \%$ was recorded. Khanum et al. (2016) reported higher infection of $E$. vermicularis in male $(1.23 \%)$ than in female $(0.65 \%)$. Highest abundance (Shannon index, $\mathrm{H}=2.51$ ) was recorded for A. lumbricoides and 
lowest abundance (Shannon index, $\mathrm{H}=0.10$ ) was recorded for $E$. vermicularis in the present investigation (Table 1).

Table 1. Prevalence of parasite species in different sexes of the host

\begin{tabular}{|c|c|c|c|c|c|c|c|}
\hline \multirow[b]{2}{*}{ Parasites } & \multicolumn{2}{|c|}{ Male } & \multicolumn{2}{|c|}{ Female } & \multicolumn{2}{|c|}{ Total } & \multirow{2}{*}{$\begin{array}{l}\text { Shannon } \\
\text { Index }(\mathrm{H})\end{array}$} \\
\hline & $\begin{array}{l}\text { Samples } \\
\text { infected }\end{array}$ & $\begin{array}{c}\text { Prevalence } \\
(\%)\end{array}$ & $\begin{array}{l}\text { Samples } \\
\text { infected }\end{array}$ & $\begin{array}{c}\text { Prevalence } \\
(\%)\end{array}$ & $\begin{array}{l}\text { Samples } \\
\text { infected }\end{array}$ & $\begin{array}{c}\text { Prevalence } \\
(\%)\end{array}$ & \\
\hline E. histolytica & 3 & 3.49 & 4 & 4.12 & 7 & 3.83 & 0.16 \\
\hline G. lamblia & 5 & 5.81 & 6 & 6.19 & 11 & 6.01 & 0.33 \\
\hline D. latum & 3 & 3.49 & 3 & 3.09 & 6 & 3.28 & 0.12 \\
\hline P. westermani & 4 & 4.65 & 3 & 3.09 & 7 & 3.83 & 0.16 \\
\hline A. lumbricoides & 24 & 27.91 & 21 & 21.65 & 45 & 24.59 & 2.51 \\
\hline T. trichura & 12 & 13.95 & 10 & 10.31 & 22 & 12.02 & 0.95 \\
\hline A. duodenale & 4 & 4.65 & 6 & 6.19 & 10 & 5.46 & 0.29 \\
\hline E. vermicularis & 0 & 0.00 & 4 & 4.12 & 4 & 2.19 & 0.10 \\
\hline
\end{tabular}

In the present study the prevalence of intestinal parasites was recorded based in different age group of different sexes. The age group 8 - 10 years showed the highest overall prevalence $(82.46 \%)$. At this age, the children usually take food and water from outside which is the main cause of being infected by these diarrhea causing agent. Hosna et al. (2018) recorded the highest overall prevalence $(91.67 \%)$ in age group 8 - 11 years which supports the present study. Dongre et al. (2007) and Khanal et al. (2011) had shown increased prevalence in 6 - 8 years of age group. In the present investigation the infection rates were recorded 83.87 and $80.77 \%$ in male and female, respectively among the children of 8 - 10 years and the lowest prevalence (39.29\%) was observed in 14 - 16 years age group. When children grow older they try to maintain their personal hygiene, daily life style and also develop immunity and tend to show less parasitic infestation. The immune system develops gradually with age. In 5 - 7 years age group, prevalence was $55.56 \%$ in male and $57.69 \%$ in female. The overall prevalence of this age group was $56.82 \%$. In case of 11-13 years age group, the infection rate was $53.70 \%$. Where in male prevalence was $56 \%$ and in female $51.72 \%$. Association between different age groups and parasitic infection was found significant at $5 \%$ level $(\mathrm{F}$ test $=4.93, \mathrm{p}$ value $=0.0009<0.05)($ Table 2$)$.

In the present study prevalence of parasite species was also observed in different age group (Fig. 1). The highest infection of E. histolytica (7.02\%) and G. lamblia (7.41\%) were found in the age group 8 - 10 and $11-13$ years. Odo et al. (2016) found highest infection of E. histolytica in $5-7$ years age group which contradicts the present finding; whereas similar G. lamblia infection was found 
by the study of Ugochi et al. (2015). In the present investigation the lowest $G$. lamblia (3.45\%) infection was found in $14-16$ years age group.

The highest infection of $D$. latum (6.90\%) and P. westermani (5.56\%) were observed in 14 - 16 and 11 - 13 years age group; while infection $D$. latum and $P$. westermani were absent in $5-7$ and $14-16$ years age group. Similar result was also found by Rashid et al. (2011).

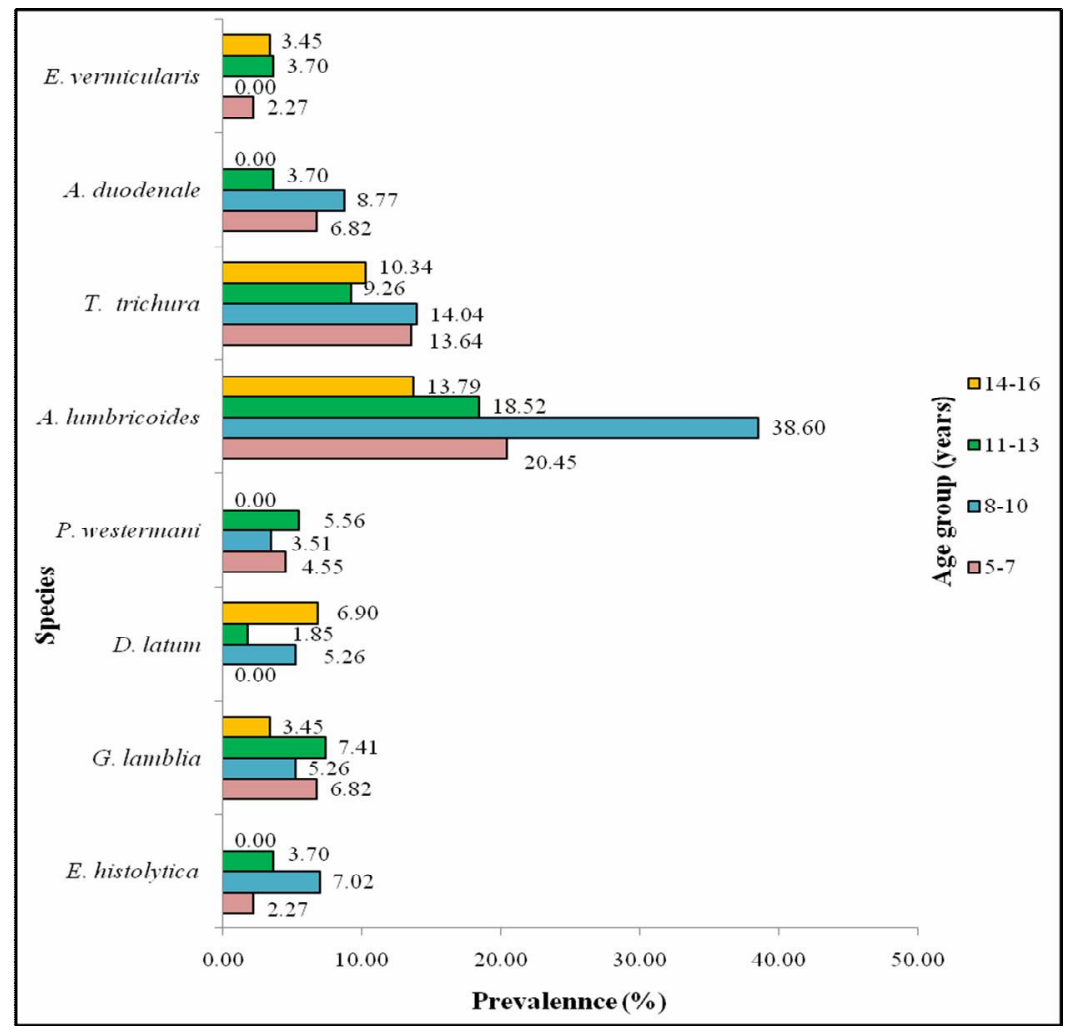

Fig. 1. Prevalence of each parasite in different age group.

Infection of Ascaris lumbricoides was recorded highest in all age groups $(20.45,38.60,18.52$ and $13.79 \%$ in $5-7,8-10,11-13$ and $14-16$ years age group, respectively). The present results are in conformity with the study of Odo et al. (2016). Mukutmoni and Khanum (2017) found highest prevalence $(42.11 \%)$ in 10 - 12 years age group.

Comparatively higher infection rate of $T$. trichura (14.04\%), A. duodenale $(8.77 \%)$ were found in $8-10$ years age group whereas, higher infection of $E$. vermicularis $(3.70 \%)$ was found in 8 - 10 years age group whereas, higher infection of E. vermicularis (3.70\%) was found in $11-13$ years age group. The 
lowest infection of $T$. trichura (9.26\%) and A. lumbricoides (13.79\%) were found in $11-13$ and 14 - 16 years age groups (Fig. 1). However, Mukutmoni and Khanum (2017) observed T. trichura (30.95\%) and A. duodenale (28.95\%), respectively in $4-6$ years and $7-9$ years age group, which contradicts the present study.

Table 2. Prevalence of intestinal parasites in different age group

\begin{tabular}{|c|c|c|c|c|c|c|c|c|c|}
\hline \multirow{2}{*}{$\begin{array}{l}\text { Age } \\
\text { group } \\
\text { (years) }\end{array}$} & \multicolumn{3}{|c|}{ Male } & \multicolumn{3}{|c|}{ Female } & \multicolumn{3}{|c|}{ Total } \\
\hline & $\begin{array}{l}\text { Samples } \\
\text { examined }\end{array}$ & $\begin{array}{l}\text { Samples } \\
\text { infected }\end{array}$ & $\begin{array}{c}\text { Preva- } \\
\text { lence } \\
(\%)\end{array}$ & $\begin{array}{l}\text { Samples } \\
\text { examined }\end{array}$ & $\begin{array}{l}\text { Samples } \\
\text { infected }\end{array}$ & $\begin{array}{c}\text { Preva- } \\
\text { lence } \\
(\%)\end{array}$ & $\begin{array}{c}\text { Samples } \\
\text { examined }\end{array}$ & $\begin{array}{l}\text { Samples } \\
\text { infected }\end{array}$ & $\begin{array}{c}\text { Preva- } \\
\text { lence } \\
(\%)\end{array}$ \\
\hline $5-7$ & 18 & 10 & 55.56 & 26 & 15 & 57.69 & 44 & 25 & 56.82 \\
\hline $8-10$ & 31 & 26 & 83.87 & 26 & 21 & 80.77 & 57 & 47 & 82.46 \\
\hline $11-13$ & 25 & 14 & 56.00 & 29 & 15 & 51.72 & 54 & 29 & 53.70 \\
\hline $14-16$ & 12 & 5 & 41.67 & 16 & 6 & 37.50 & 28 & 11 & 39.29 \\
\hline F-test & & & & & 4.93 & & & & \\
\hline $\mathrm{p}$ & & & & & 0.0009 & & & & \\
\hline
\end{tabular}

It was assumed that the infection of parasites decreases with the increase of age since children become aware to maintain their personal hygiene and daily life style. Thus they can develop immunity and tend to show less parasitic infestation. The highest abundance (Shannon index, $\mathrm{H}=1.47$ ) of parasites was observed in 8 - 10 years age group and lowest (Shannon index, $\mathrm{H}=0.92$ ) in 14 16 years age group. In $5-7$ and $11-13$ years age groups Shannon index, $\mathrm{H}=$ 1.28 and 1.33 were recorded in the present study (Table 2).

\section{CONCLUSION}

In the light of the present study, it can be concluded that the school going children of slum area have high prevalence of intestinal parasites. Parents of the children might not be conscious about what they eat and what they use for their daily life and exposure to infection is influenced by climate, poverty, ignorance, lack of access to safety measures and personal hygiene. These infections affect the psychological and physical development of a child. Therefore, multiple intervention strategies should be implemented not only for the children but also for households and the environment to reduce the disease burden.

\section{LITERATURE CITED}

AHMED, T., KHANUM, H. and HOSSAIN, A. 2013. Prevalence of Trichuris trichiura among the children of age under five years. Bangladesh J. Zool. 41(1): 97-103.

ALAM, S.M. and KHANUM, H. 2005. Infection of Ascaris lumbricoides and Trichuris trichiura among the children of two slum areas in Dhaka city. Bangladesh J. Zool. 33(1): 89-94. 
ALI, I., MEKETE, G. and WODAJO, N. 1999. Intestinal parasitism and related risk factors among students of Asendabo Elementary and Junior Secondary school, South Western Ethiopia. Ethiop. J. Heal. Dev. 13: 157-161.

BERKMAN, D.S., LESCANO, A.G., GILMAN, R.H., LOPEZ, S.L. and BLACK, M.M. 2002. Effects of stunting, diarrhoeal disease, and parasitic infection during infancy on cognition in late childhood: a follow-up study. Lancet 359(9306): 564-571.

CHATTERJEE, K.D. 2014. Parasitology: Protozoology and Helminthology with two hundred fourteen illustrations. (Ed., 13 ${ }^{\text {th }}$ ). CBS Publishers \& Distributors Pvt. Ltd. pp. 19.

DONGRE, A.R., DESHMUKH, P.R., BORATNE, A.V., THAWARE, P. and GARG, B.S. 2007. An approach to hygiene education among rural Indian school going children. Online J. Health Allied Scs. 4: 2-7.

FELEKE, M. 2010. Comparision of formal-acetone concentration method with that of the direct iodine preparation and formol-ether concentration methods for examination of stool parasites. Ethiop. J. Health Dev. 24(2): 148-151.

GARZON, M. 2003. Parasites-A holistic approach. In: Associates NIH, Washington: Capital University of Integrative Medicine. pp. 143.

GElaW, A., ANAGAW, B., NIGUSSIE, B., Silesh, B., YIRGA, A., ALEM, M., ENDRIS, M. and GELAW, B. 2013. Prevalence of intestinal parasitic infections and risk factors among school children at the University of Gondar Community school, Northwest Ethiopia: A cross-sectional study. BMC Public Health. 13: 304-312.

HAQUE, R., MONDAL, D., KIRKPATRICK, D., AKHTER, S. and PETRI, W.A. 2003. Epidemiologic and clinical characteristics of acute diarrhea with emphasis on Entamoeba histolytica infections in preschool children in an urban slum of Dhaka, Bangladesh. Am. J. Trop. Med. Hyg. 69(4): 398405.

HOSNA, A., KHANUM, H. and NAHAR, A. 2018. Occurrence of intestinal parasites among the slum children. Biores. Commun. 4(1): 470-475.

KHANAL, L.K., CHOUDHURY, D.R., RAI, S.K., SAPKOTA, J., BRAKOTI, A. and HADA, S. 2011. Prevalence of intestinal worm infestations among school children in Kathmandu, Nepal. Nepal Med. Coll. Lnl. 13(4): 272- 274.

KHANUM, H. MUKUTMONI, M., UDDIN, J. and HAQUE, R. 2016. Diarrheal carriage illness with Trichuris trichiura among the slum dwelling children in Dhaka city. Biores. Commun. 2(2): 254258.

KHANUM, H., ISLAM, M.N. and DHAR, T. 1997. Prevalence of Ascaris lumbricoides and Trichuris trichura among the children of four slum areas in Dhaka city. Univ. J. Zool. Rajshahi Univ. 16: 89-94.

KHANUM, H., NAHAR, N., KARIM, M.T. and BANU, H. 2016. Infection of protozoan and helminth parasites among the out-patients of Dhaka Medical College Hospital. Bangladesh J. Zool. 44(1): 89-97.

KUMAR, S., SINGH, J. and KUMAR, A. 2017. Prevalence and correlation of soil transmitted helminth infection to the degree of anemia and nutritional status among pediatric patients of age group 6 - 14 years in Kishanganj, Bihar, India. Int. J. Contemp. Pediatr. 4(1): 223-231.

LIU, L., JOHNSON, H.L., COUSENS, S., PERIN, J., SCOTT, S., LAWN, J.E., RUDAN, I., CAMPBELL, H., CIBULSKIS, R., LI, M., MATHERS, C. and BLACK, R.E. 2010. Global, regional, and national causes of child mortality: An updated systematic analysis for 2010 with time trends since 2000 . Lancet 379(9832): 2151-2161.

MUKUTMONI, M. and KHANUM. H. 2017. Prevalence and risk factors of intestinal helminthiasis among the children of Begun Bari slum, Tejgaon, Dhaka. Bangladesh J. Zool. 45(2): 123-129. 
NEMATIAN, J., GHOLAMREZANEZHAD, A. and NEMATIAN, E. 2008. Giardiasis and other intestinal parasitic infections in relation to anthropometric indicators of malnutrition: A large, populationbased survey of school children in Tehran. Ann. Trop. Med. Parasitol. 102(3): 209-214.

ODO, G.E., AGWU, J.E., EKEH, F.N., EZEA, C.O., AGUORU, G.C., ANYA, C., OMEJE, K.O. and UBACHUKWU, P.O. 2016. Prevalence of intestinal parasites among school children in UzoUwani Local Governemnt area of Enugu state. Int. J. Res. Stu. Microbiol. Biotech. 2(2): 7-14.

ONYIDO, A.E., ANUMBA, J.U., EZECHUKWU, G.C., UGHA, C., UMEANAETO, P.U. and IWUEZE, M.O. 2017. Intestinal helminth infections among primary school pupils in Ekwulumili Community, Nnewi South Local Government Area, Anambra State. Nigerian J. Parasitol. 38(2): 17-24.

PLANNING COMMISION. 1973. The first five year plan 1973-1974. Ministry of Planning, Bangladesh. pp. 549.

RAO, V., SUGUNAN, A., MURHEKAR, M. and SEHGAL, S. 2006. Malnutrition and high childhood mortality among the Onge tribe of the Andaman and Nicobar Islands. Public Health Nutr. 9: 19-25.

RASHID, A.M., RASHID, A.S. and RAHMAN, A. 2011. Prevalence of intestinal parasitoses in urban and rural children of a developing country. Asian Pac. J. Trop. Biomed. 1(2): 268-270.

SCHIMDT, G.D. and ROBERTS, L.S. 1989. Foundation of Parasitology. Times Mirror/Mosby College Pub. Science.750 pp.

SEID, M., DEJENE, T. and TOMASS, Z. 2015. Prevalence of intestinal helminths and associated risk factors in rural school-children in Were-abaye sub district, Tigray region, Northern Ethiopia. APG 6(1): 29-35.

SHANNON, C.E. and WIENER, W. 1949. The Mathematical Theory. University of Illinois Press, Urbana, USA. pp. 117.

SHARMA, B.K., RAI, S.K., RAI, D.R. and CHOUDHURY, D.R. 2004. Prevalence of intestinal parasitic infestation in school children in the northeastern part of Kathmandu Valley, Nepal. Asian $J$. Trop. Med. Publ. Health. 4(10): 11-14.

STEKETEE, R.W. 2003. Pregnancy, nutrition and parasitic diseases. J. Nutr. 133: 1661-1667.

UDDIN, M.H. and KHANUM, H. 2006. Hemoglobin level among adolescent girls and it's relation to intestinal parasites. Bangladesh J. Zool. 32(2):183-188.

UGOCHI, U.J., IFENYINWA, M.C., IJEOMA, E., GODSON, U.M. and NWAKU, A.I. 2015. Prevalence of intestinal parasites among primary school children in three geopolitical zones of Imo State, Nigeria. Sci. J. Public Health. 3(5-1): 25-28.

VICTORA, C.G., HUTTLY, S.R., FUCHS, S.C., BARROS, F.C., GARENNE, M., LEROY, O., FONTAINE, O., BEAU, O., FAUVEAU, V. and CHOWDHURY, H.R. 1993. International differences in clinical patterns of diarrhoeal deaths: A comparison of children from Brazil, Senegal, Bangladesh, and India. J. Diarrhoeal Dis. Res. 11(1): 25-29.

VILWANATHAN, S.A., YASHWANTH, JAYACHANDRAN, A.L., KANDASAMY, B. and VIJAYALAKSHMI, T.S. 2017. Prevalence of intestinal parasitic infections and predisposing factors among children in field practice area of tertiary care centre in South India. Int. J. Med. Microbiol. Trop. Dis. 3(2): 45-49.

WORLD HEALTH ORGANIZATION/WHO. 2002. Reducing risks promoting healthy life. WHO Rep. pp. 19. 